\title{
FROM INDUSTRY TO CULTURE: REGENERATION of GOLDEN HORN AS A "CULTURAL VALLEY"
}

\author{
Ceyda BAKBASSA BOSSON \\ École Polytechnique Fédérale de Lausanne \\ ceyda.bakbasa@epfl.ch \\ https://orcid.org/0000-0001-5490-3019 \\ Evrim TÖRE \\ İstanbul Kültür University, Turkey \\ e.tore@iku.edu.tr \\ https://orcid.org/0000-0001-6720-0232
}

\begin{abstract}
The image shifts from industrial identity to cultural identity since 1980s in Golden Horn, one of Istanbul's former industrial areas, encompassed cultural policies and urban regeneration processes in the area. This study discusses the positions of public and private sector investments in the region during the process of creating "The Golden Horn Cultural Valley" and reveals the policies that managed this regeneration. The research uses a multi-dimensional method considering both qualitative and quantitative data throughout economics, politics/urban cultural policies, society, culture and space. With respect to the projects, the authors highlight three main outcomes: (1) processes vary according to the actors, (2) lack of integrated vision and (3) disconnected cultural visibility.
\end{abstract}

Keywords: post-industrial space, entrepreneurialism, Golden Horn, culture-led regeneration, urban policies, arts.

\section{SANAYİDEN KÜLTÜRE: HALİÇ’IN “KÜLTÜR VADİSI’NE DÖNÜŞÜMÜ}

\section{ÖZ}

1980'lerden bu yana sanayi kimliğinden kültürel kimliğe geçiş, İstanbul'un eski sanayi bölgelerinden biri olan Haliç'te, bölgedeki kültürel politikaları ve kentsel dönüşüm süreçlerini kapsamıştır. Bu çalışma "Haliç Kültürü Vadisi" oluşturma sürecinde bölgedeki kamu ve özel sektör yatırımlarının konumlarını tartışmakta ve bu yenilenmeyi yöneten politikaları ortaya koymaktadır. Araştırmada, ekonomi, siyaset/kentsel kültür politikaları, toplum, kültür ve mekan üzerine hem nitel hem de nicel verileri dikkate alan çok boyutlu bir metodoloji kullanılmaktadır. Projelerle ilgili olarak, yazarlar üç ana çıktının altını çizmektedir: (1) süreçler aktörlere göre değişmektedir, (2) entegre vizyon eksikliği söz konusudur ve (3) kültürel görünürlükte kopukluklar belirlenmiştir.

Anahtar Kelimeler: post-endüstriyel sanayi mekanlarl, girişimcilik, Haliç, kültür-eksenli dönüşüm, kentsel politikalar, sanat. 


\section{INTRODUCTION}

During the deindustrialisation period that followed the structural crisis of 1970, the loss of dominant economic functions in cities triggered social and spatial collapse, particularly in urban centres. This period affected old industrial cities, notably those in North America and Western Europe, and lasted until the 1980s. Therefore, the 1980s witnessed changes in the production model, in terms of the service sector and trends of capital flow to certain cities. Consequently, such cities attempted to attract service sector investments. The first effective measures that were able to diminish these effects began to be enacted through urban regeneration projects that were shaped through public and private sector partnerships. These projects were initially conducted in the field of real estate. An important body of literature details the failures of this regeneration mentality, which aimed to attract new economic investments through an "improved" city image using real estate projects, such as housing, office buildings and shopping centres by regenerating former industrial areas and docs.

The emergence of culture in regeneration projects became possible with the launch of tourism-led urban regeneration projects. New tendencies in competitiveness, of cities place marketing efforts allow culture to locate in the centre of urban regeneration projects in the 1990s. From then on, culture has become an embodied instrument that brings economic yield rather than being a field that is subsidised by the state. The concern of creating an urban brand in cultural regeneration projects gained strength, and culture became an element of marketing and investment within private sector initiatives that were triggered during the neo-liberalisation period. During this period, an approach was established in which culture was addressed through beautification efforts and improvements to the image of the city through spatial regeneration over time (Evans and Shawn, 2004; Evans, 2005a, b). Culture-led regeneration has been observed in three ways: flagship projects, events and cultural quarters (Hetherington, 2008; Teske, 2006; Garcia, 2004; 2005; Landry, 2006; Kunzmann, 2004). Flagship projects, including the large showy structures of famous architects, can be considered to initiate regenerations of the region. Urban icons such as the Guggenheim Museum (Bilbao), the Golden Gate Bridge (San Francisco) and the Cloud Gate (Chicago) are examples of flagship projects. Events include activities such as the Barcelona Olympics of 1992, the Glasgow ECOC of 1990 and the Expo (Seville) and play an important role in a city's culture-led regeneration. Cultural quarters can be described as complexes where production, exhibition and consumption take place alongside support sectors. In this context, Birmingham's Lace Market and Dublin's Temple Bar (DCMS, 2004; UNCTAD, 2008, 2010; KEA, 2006; Garcia, 2004, 2005; Landry, 2006) are examples of cultural quarters that play important roles in new competitive environments.

Although the story of deindustrialization is different, the shores of the Golden Horn have undergone a culture-oriented transformation since the 1980s in parallel with the examples mentioned above. Among the most prominent elements of this transformation are; the Koç Museum, one of the first flagships of the region initiated by a famous industrial company, Santrallstanbul which is the first multi-dimentional complex in Turkey that functions as a university-museum-artist workshops in-one, Miniaturk, which is a public-based flagship, Feshane, which is another public initiative and FenerBalat, a culture-tourism project that can be considered as a part of the culture-based transformation. This study discusses the positions of public and private sector investments in the region during the process of creating a cultural valley in the Golden Horn, which seems partitive, discontinuous and, in a sense, isolated. In this context, our aim is to examine the regeneration process of the Golden Horn through key actors in cultural policies regarding spatial reflections and implementation processes. In this manner, this study differs from previous studies that have addressed topics such as migration, regeneration of industrial structures and transportation in the Golden Horn region.

The research contains the period of 1980-2012 with important breaks. Two factors played a role in excluding the developments after 2012 from the scope of the study. First, discussions on the cultural valley and the items that make up the valley have become ripe and measurable between the years 1980-2012. The second reason is that many of the changes in the Golden Horn and the surrounding 
area since 2013, the regeneration projects on various scales and the socio-political awareness have brought a different perspective from the period until 2012. This new perspective entails the debate on "the right of the city and the cultural politics" instead of "culture, space and investment", therefore it is incompatible with the theme and the method of this article.

\section{Methodology}

This study uses a multi-dimensional method that strives to understand processes as outcomes of both qualitative and quantitative data on economics, politics/urban cultural policies, society, culture and space. In addition to local and upper-scale projects conducted in the Golden Horn, 20 in-depth interviews are realized about site-selection decisions of the region's important cultural investors.

The profile of actors for interviews is classified according to their role and characteristic in the process of transformation of Golden Horn. Within this framework, we have identified 4 different profiles having a fundamental role.

(1) Public Actors: Public actors involved in the process are divided into two categories, including the public actors at the local level and the national level. The aim of interviews with these two categories is to understand their role defined by themselves along the transformation of Golden Horn and their action for the implementation of cultural regeneration projects. These interviews allowed us to see whether there is a global vision of public actors and how intergovernmental coordination between these categories have worked out during the transformation process.

(2) Private actors: Interviews with private actors were held with managers of cultural facilities of Santralistanbul, the Rahmi Koç Museum and other private investments located in the area. We tried to understand the reason behind their choice of location in Golden Horn and their interaction with the valley.

(3) Inhabitants and visitors: The different socio-economic situation of inhabitants in Eyup, Gaziosmanpasa, Beyoglu and Fatih, where the transformation project is located, was determinant for the interviews. They showed us how inhabitants have perceived the regeneration process in Golden Horn and what these cultural projects implemented their neighborhood means to them.

(4) NGOs and others: This profile contains independent and multi-stakeholder actors who are not directly linked to the implementation of regeneration projects in the valley but who nevertheless are in the process of transformation. The purpose of these interviews is to determine how these independent and multi-stakeholder actors participate in the decisionmaking process.

\section{The Golden Horn Cultural Valley}

The Golden Horn (Haliç) is a natural internal port approximately $8 \mathrm{~km}$ in length. It is surrounded by the neighbourhoods of Beyoğlu, Fatih, Eyüp and Kağithane (Yücetürk, 2001) and covers an area of 25 million square metres (Baştürk et al., 2001) (Figure 1, Photo 1).

It is important to evaluate the Golden Horn's regeneration process through key points at different historical moments. the Golden Horn served as an administrative centre and harbour during the Byzantine period and then became an intense trade centre during the Ottoman period. These developments can be considered key components of the region's identity. 
At another key moment, the Golden Horn developed an industrial identity during the larger global industrialisation process. Thus, from the $19^{\text {th }}$ century onwards, the Golden Horn developed as an industrial zone. Buildings such as the Feshane (1833), where textiles and fezzes were produced for the ottoman army (Müller-Wiener, 1992), and the Silahtarağa (1911), the electrical plant (Cengizkan, 2006), are fragments of this industrial heritage that still exist today.

The period between 1929 and 1939, followed by the establishment of the Republic, can be considered a central period that witnessed the growing prominence of national identity and the development of industrialisation policies. During this period, integrated policies that aimed to develop the country were implemented with the objective of creating a city with the hallmarks of the new republic. In this context, the Golden Horn became the industrial zone of the city, specifically through Henri Prost's plan (1937) (Suhen, 2004; Bilsel, 2007, Bilsel, 2011; Eyice, 2002; Aydemir, 2008). The slaughterhouse of Sütlüce (1923) is one example of an important structure of the period.

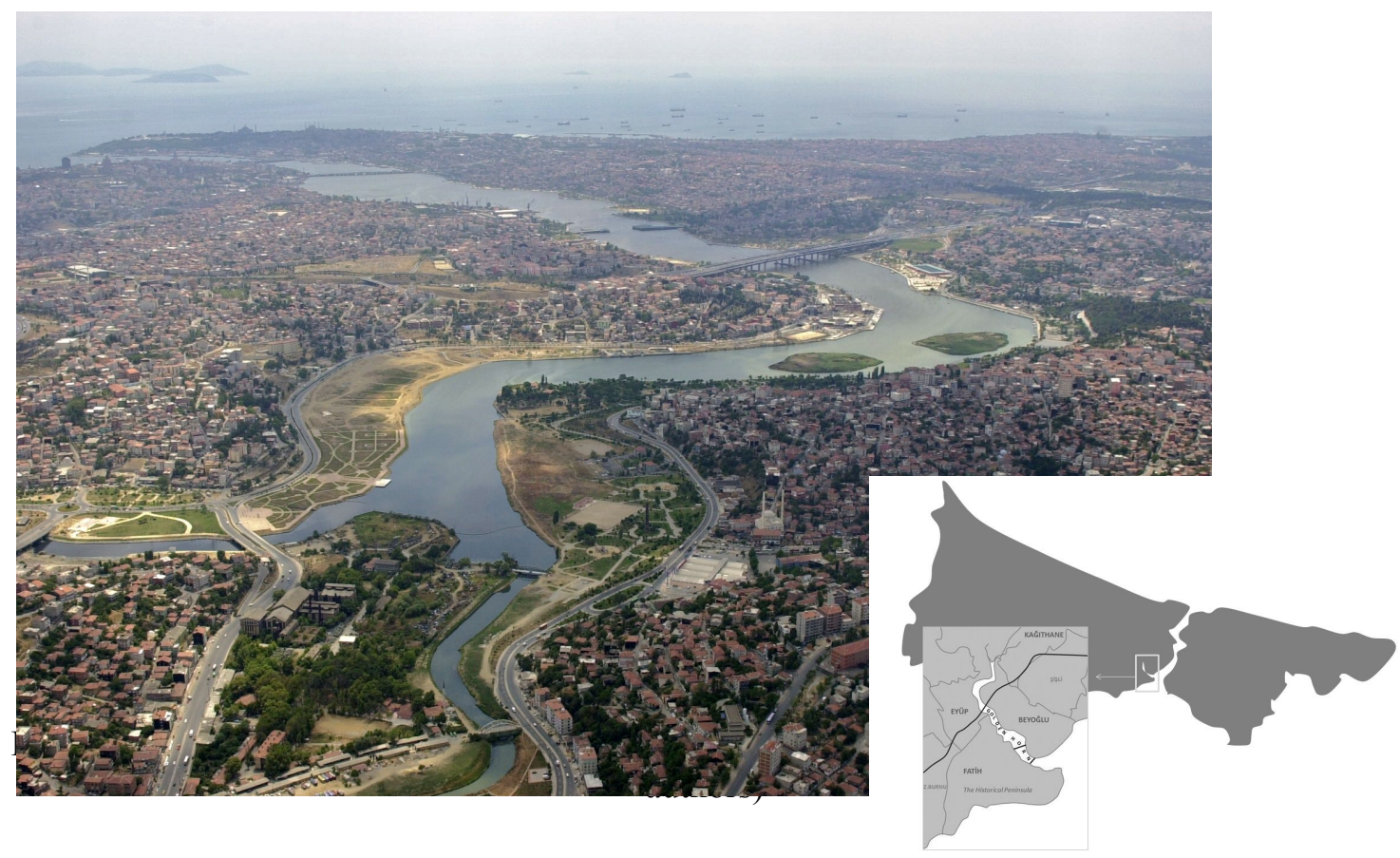

Figure 1. The Golden Horn (photo: The archive of Eyüp Municipality, 2011, map: made by the authors)

In the 1950s, due to the changed political environment after the Second World War, the city entered a period of restructuring. More than 700 manufacturing plants and 2,000 related businesses were established specifically in the Golden Horn region during this period (Eroğlu et al., 2004). Industrialisation-related migration led to the first seeds of gecekondus, particularly in the Kağtthane and Zeytinburnu districts, causing rapid urbanisation and visible pollution in the Golden Horn during the period (Yücetürk, 2001). Opening the banks of the Golden Horn to industrial activities resulted in destruction of both natural resources and the fabric of the old city. The large-scale reconstruction operations, known as the Menderes Operations, that took place during this period also supported industrial developments in the Golden Horn (K1lıç and Yenen, 2001).

During the first period of the Republic (1933), the first steps toward culture-led development of the Golden Horn were taken with Elgötz's plan. In addition, the Piccinato report suggested deindustrialisation and reconstruction of the Golden Horn in a way that would encourage tourism and the cultural potential of Istanbul (1958). As part of the following period's industry plan (1966), 
industrial sites on the banks of the Golden Horn were cancelled. Although this decision failed to prevent the destruction of the fabric of the Golden Horn, it may be viewed as an effective breaking point in the regeneration process. As observed in the 1/5000 Scale Istanbul Walled City Master Plan approved in 1964, the Piccinato plan was adopted. To benefit from tourism opportunities, the banks of the Golden Horn on the Historic Peninsula were considered to be in need of improvement.

In the 1980s, the Golden Horn moved rapidly away from its industrial nature. Municipalities gained authorisation for development plans through the Law on Metropolitan Municipalities (No. 3030) and the Law on Development Plan (No. 3194), which came into force in 1984 and 1985, respectively (K1lıç and Yenen, 2001; Suhen, 1994). The following statement made by Bedrettin Dalan, former mayor of the Istanbul Metropolitan Municipality (IMM) between 1984 and 1989, served as the primary intervention in the process of regeneration and in the initiative to decontaminate the waters of the Golden Horn: "I will make the waters of the Golden Horn as blue as my eyes!" (Karaman, 2012). During this period, many industrial and residential buildings were razed, and new recreational areas were created in the Golden Horn. The Dalan administration is criticised for eliminating structures that had comprised the industrial identity of the Golden Horn (Kilıç and Yenen, 2001), which caused the collapse of historical areas (Keleş, 2003), and for not evaluating the process; therefore, these interventions are considered an important breaking point for Istanbul (Keyder and Öncü, 1993; Keleş, 2003; Tekeli, 2001; Erden, 2003). Although the Dalan administration was not entirely successful in decontaminating the waters of the Golden Horn, it initiated an important period that would make progress towards that goal.

The vision of a global city during the Dalan period (Öktem, 2006; Keyder, 2000) was changed with local policies of Mayor Nurettin Sözen (Ekinci, 1994), who was the mayor of Istanbul between 1989 and 1994 from Social Democrat Party. His vision for Istanbul was different from the previous mayor Bedrettin Dalan. Instead of pointing out Istanbul as a global city, he mentioned the need of social development not the five stars hotel. The following municipal period was of Erdoğan's, who governed Istanbul between 1994 and 1998 from Welfare Party (Refah Partisi). He indicated the continuation of the process through neoliberal policies (Öktem, 2011). His vision was similar to Dalan's, but the Islamic values were present in a lot of project proposed for Istanbul. Besides, the participation of private sector in urban transformation and a brand developed under the tourism, cultural and financial opportunities of Istanbul were the important solutions for Istanbul's image. Therefore, the master plan 1995 reflects the presence of cultural and tourism strategies for the development of Istanbul.

Ali Müfit Gürtuna, the next mayor in between 1998 and 2004 was from Virtue Party which is the continuity of Welfare Party. Along with the similarity of two political parties, the vision of Gürtuna was the continuity of Erdoğan's vision. Golden Horn Cultural Valley was one of the projects of Gürtuna. Although the notion of the Golden Horn as "the valley of culture" was evoked by him, it must be evaluated as a process shaped since the Dalan administration.

Another turning point for the Golden Horn was the Environmental Master Plan of Istanbul (2009), which promoted the protection of the landscape, skyline and historical and cultural fabric of the region while also promoting "the Golden Horn Cultural Districts". The plan brought about the use of industrial structures and shipyards of the Golden Horn in cultural and educational activities and provided clues for involving the private sector. Thus, the Golden Horn obtained a cultural identity through the vision and scope of a larger scale plan. After 2012, many infrastructural and tourismoriented projects were planned and realized in Golden Horn. We prefer to consider these projects as a part of the rectification process of Istanbul to a global city rather than the regeneration of Golden Horn into a cultural valley.

Many flagship projects addressed in the Golden Horn's regeneration process can be found in Figure 2. These projects are classified as private sector investments, local government initiatives and urban 
renewal projects, depending on those involved in the projects.

\section{Private Sector Investments}

Private sector initiatives are one of the important actors in cultural investment and urban regeneration in Turkey. Along with the neoliberal policies starting the 1980s, the approval of the Law on Encouragement of Tourism in 1980 and the Law on Improvement of Cultural Investment and Initiative in 2004 procured the strong participation of private sector in cultural policies in Turkey, especially in Istanbul. Koç, Sabancı and Eczacıbaşı Families are the leaders in cultural investment and events.

Private sector investments in the Golden Horn are one of the important initiators in the region's culture-led regeneration process. Most of these projects were designed to rehabilitate the industrial heritage of the Golden Horn, and public figures were partially involved in the process. However, it is important to note here that the public's involvement depends on the nature of the project and on the nature of the area. For example, the role of local governments was quite different for the Rahmi Koç Museum and Santralistanbul projects because the industrial structures of these two regions were owned by central government bodies, as will be discussed below.

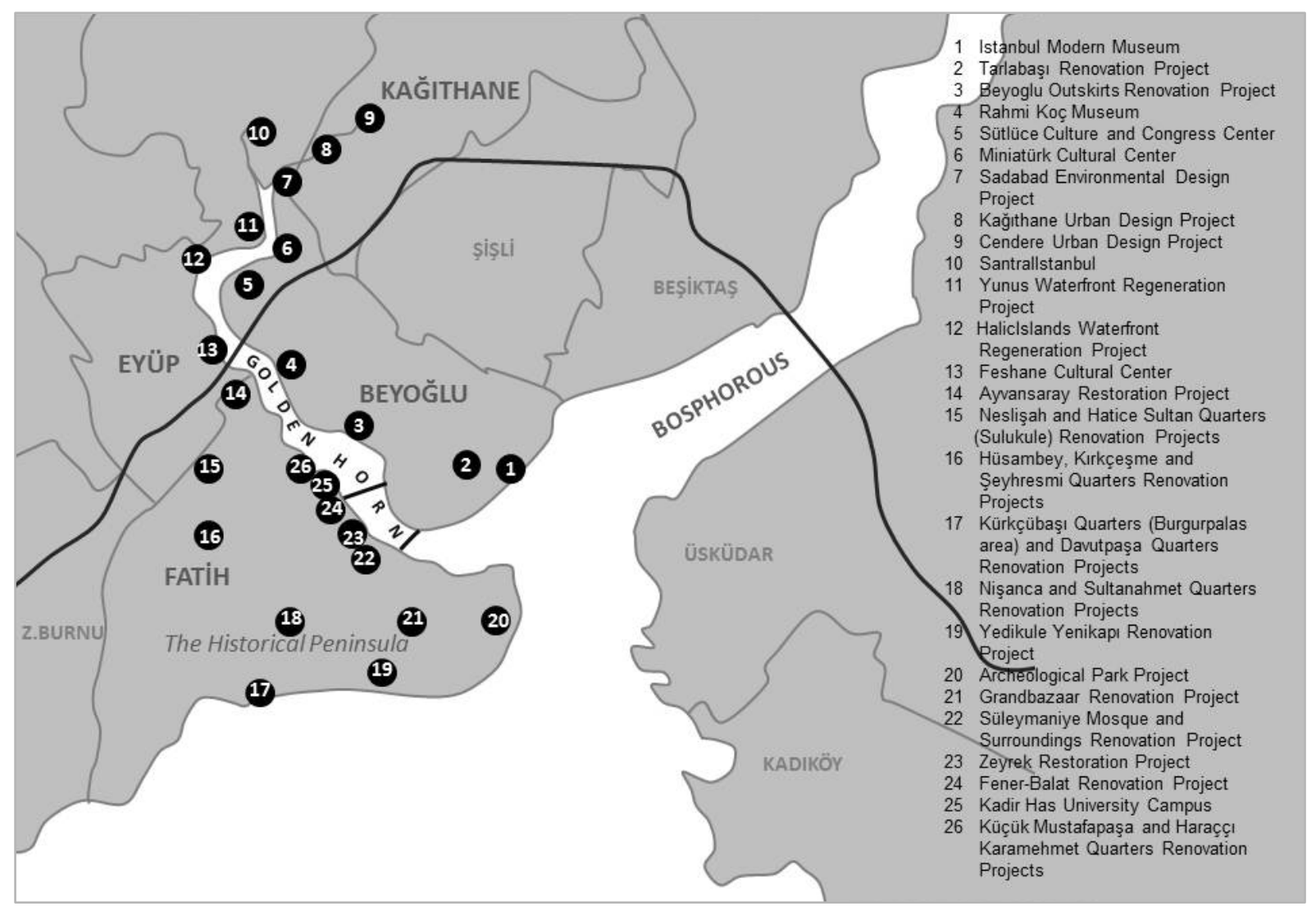

Figure 2. Main Projects in and around the Golden Horn region (compiled by the authors)

The private sector's interest in the Golden Horn parallels Dalan operations dating back to the 1980s. Large-scale private sector investments in Golden Horn focus primarily on culture and they occupy also an important place in Istanbul's cultural infrastructure and milieu. Significant private sector investments that demonstrate current-day existence of culture in the valley include the Rahmi Koç 
Museum (1994) established by the Rahmi Koç Foundation, the Cibali Tobacco Factory (1997), which was transferred to Kadir Has University by the Kadir Has Foundation, Santralistanbul, which was created by transforming the Silahtarağa power plant, and the Istanbul Bilgi University campus (2007). To analyse the place of these private sector investments in discourse around the Golden Horn Cultural Valley, the Santralistanbul project, which aimed to create an international image and dialog, and the Rahmi Koç Museum, which was one of the first private sector investments in the valley and provided cultural expansion on a local scale, will be discussed.

\section{(1) The Rahmi Koç Museum}

The Rahmi Koç Museum, one of the first and most important examples of private sector investments to use the industrial heritage of the Golden Horn as cultural infrastructure, emerged with the regeneration of the Hasköy Shipyard and the Lengerhane built during the reign of Ahmet III (1703 1730) for the production of chains and anchors for ships (Köksal, 2004). The Lengerhane was used as the depot for the Turkish State Liquor and Tobacco Monopoly during the Republican era; it became useless after the 1984 fire and was in constant regeneration from May 1991 onward (Ibişoğlu, 1991; Günay and Dökmeci, 2011). After seeing the Henry Ford Museum, Rahmi Koç, an important figure in Turkish business, decided to establish a similar museum, which led to the establishment of the Rahmi Koç Museum (interview, Selçuk Kolay, February 1st, 2011). Because an industrial museum was the aim, the Koç Foundation preferred the Lengerhane, characterised by its industrial identity. The Hasköy Shipyard was also included in the Rahmi Koç Museum complex in 2001.

The museum attracted up to 2,000 visitors during the first few years after it was opened (interview, Selçuk Kolay, February 1st 2011); currently, 200,000 individuals, primarily composed of student groups, visit the museum per year (interview, Yeşim Anadol Zengin, February 3rd 2011; interview, Selen İşyar, February 3rd 2011). The museum attracts few foreign visitors, and they constituted only $2 \%$ of 2008's private museum visitors in Istanbul (Bakbaşa, 2010). As observed by the number of people visiting the museum and the organisation's goals, the Rahmi Koç Museum was developed out of a personal initiative rather than an aim to strengthen the cultural image of Istanbul on an international scale (Bezmez, 2008). The target audience was, hence, shaped accordingly.

The Rahmi Koç Museum's place in the culture-led regeneration of the Golden Horn can be examined in the following three ways: (1) the efficiency of the actors in the museum's founding process, (2) attitudes of the region's inhabitants towards the project and (3) the private sector's increasing interest in the region since 2007.

The central government and the private sector are viewed as the key actors in the development of this project (Bezmez, 2008). Prior to acquisition by the Rahmi Koç Foundation, the location of the museum was a former protected area and was owned by the Ministry of Transport and the Cibali Tobacco Factory (Ibişoğlu, 1991), which clearly indicates the effectiveness of the central government in the process. However, the IMM and the district municipality were not involved in the project as much as the central government was (Bezmez, 2008). The district municipality and the IMM were not described as key actors during the museum's founding (interview, Yeşim Anadol Zengin, February 1st, 2011; interview, Selen İşyar, February 3rd, 2011; interview, Selçuk Kolay, February 1st 2011), which is reflected in the plans. There was no clear decision that overlapped with the vision of the Golden Horn Cultural Valley in the 1/5000 scale Master Plan of Hasköy, Sütlüce, and Halıcioğlu neighbourhoods. Therefore, the local governments were involved in the process for the sake of formality rather than complementarity.

When the views of local residents were evaluated, they generally considered the Rahmi Koç Museum to be an important landmark that strengthens the image of the region. However, this feature did not go beyond merely describing the space in which they work (interview, İbrahim Sayfi, February 4th, 2011; 
interview, Süleyman Kul, February 4th, 2011). Therefore, the museum was effective on a local scale but is in an isolated location. The second point highlighted regarding the museum's impact on the region argues that the museum did not trigger a large change in the cultural sense (interview, Ferhan Yeltırak, February 4th 2011; interview, Murat Karakaya, February 4th 2011) but caused an increase of approximately $1,000 \%$ in real estate prices, particularly after the acquisition of the Hasköy Shipyard in 2001 (Beyoğlu Municipality, 1990-2010). While the square metre value was 279 TL in 2008 on Imrahor Avenue where the museum is located, it rose to 3.400 TL in 2010 (Beyoğlu Municipality, 1990-2010).

However, these changes cannot be limited to the Rahmi Koç Museum. Thus, the Sütlüce and Hasköy neighbourhoods began to attract the private sector beginning in 2007 (Gümüş, 2011; Şentürk, 2010). Public expectations were constituted by a number of factors, including the founding of the ddF fair in 2009, the provincial headquarters of the Justice and Development Party (JDP- Ak Parti) and the head office of MUSIAD (Müstakil Sanayici ve İşadamları Derneği - Institution of Individual Industrial and Businessman) in 2007, the Hilton Garden Inn Hotel in 2011, rumours of future local investments by the Sabanc1 group (interview, Sinan Atabey, February 4th 2011), the acquisition of a portion of the neighbourhood by the Çalık group (Gümüş, 2011) and the regeneration of the Hasköy Wool Yarn Factory into a shopping centre (interview, Sinan Atabey, February 4th 2011).

The interviews state that the Museum caused a change in real estate prices, but the actual increase occurred when a site for the JDP's provincial headquarters was selected in the district. Although it is difficult to estimate the effect of the district municipality or the IMM on this change, it is certain that they supported the change in Hasköy in line with the private sector's interests. For example, the requirement that new planning studies utilise additional investments was argued after the Holiday Inn was constructed (interview, Şuayip Korkmaz, September 14th, 2011). However, similar initiatives were not undertaken for the Rahmi Koç Museum. Therefore, discourse about the Golden Horn Cultural Valley planned by many local governments in the last 30 years and reflected in the upperscale plans failed to affect lower-scale plans and was not addressed in an integrated way.

\section{(2) Santralistanbul}

Another private sector initiative in the Golden Horn Cultural Valley was the regeneration of the Silahtarağa Power Plant into Santralistanbul and the Istanbul Bilgi University Campus. Established in 1911 and beginning production in 1913 in an area of 118,000 square metres, the Silahtarağa Power Plant was established to generate electricity for Istanbulites (Kayserilioglu, 1999; Kara, 1994; Cengizkan and Köksal, 2004). In addition to producing electricity, the plant was seen as an instrument of modernisation (Kayserilioglu, 1999) and ceased operations in 1983 (Kara, 1994). The plant was then abandoned and put under conservation according to decision no. 2532 in 1991 (Kara, 1994). From 2002, the project was on the Bilgi Foundation's agenda (interview, Serhan Ada, November $16^{\text {th }}$, 2011) and was transferred to the Ministry of Energy and Natural Resources on May 1, 2004, with a 20 -year renewable contract (Aksoy, 2007; Ethem, 2009). The aim was to put the former power plant into action with the culture- and education-oriented Santralistanbul project (Paşaoğlu, 2007; Arolat et all., 2007; Köksal and Ahunbay, 2006) (Photo 1).

The Santralistanbul project aimed to create multi-dimensional and interdisciplinary dialog and to achieve international cultural production (interview, Serhan Ada, November 16th, 2011). Unlike the Rahmi Koç Museum, the Santralistanbul project also aimed to establish a presence in the international cultural platform (interview, Serhan Ada, November 16th, 2011). References to the Tate Modern Museum and the Centre Pompidou in the Santralistanbul project promotional leaflet confirm this approach (Grouiller, 2005). 


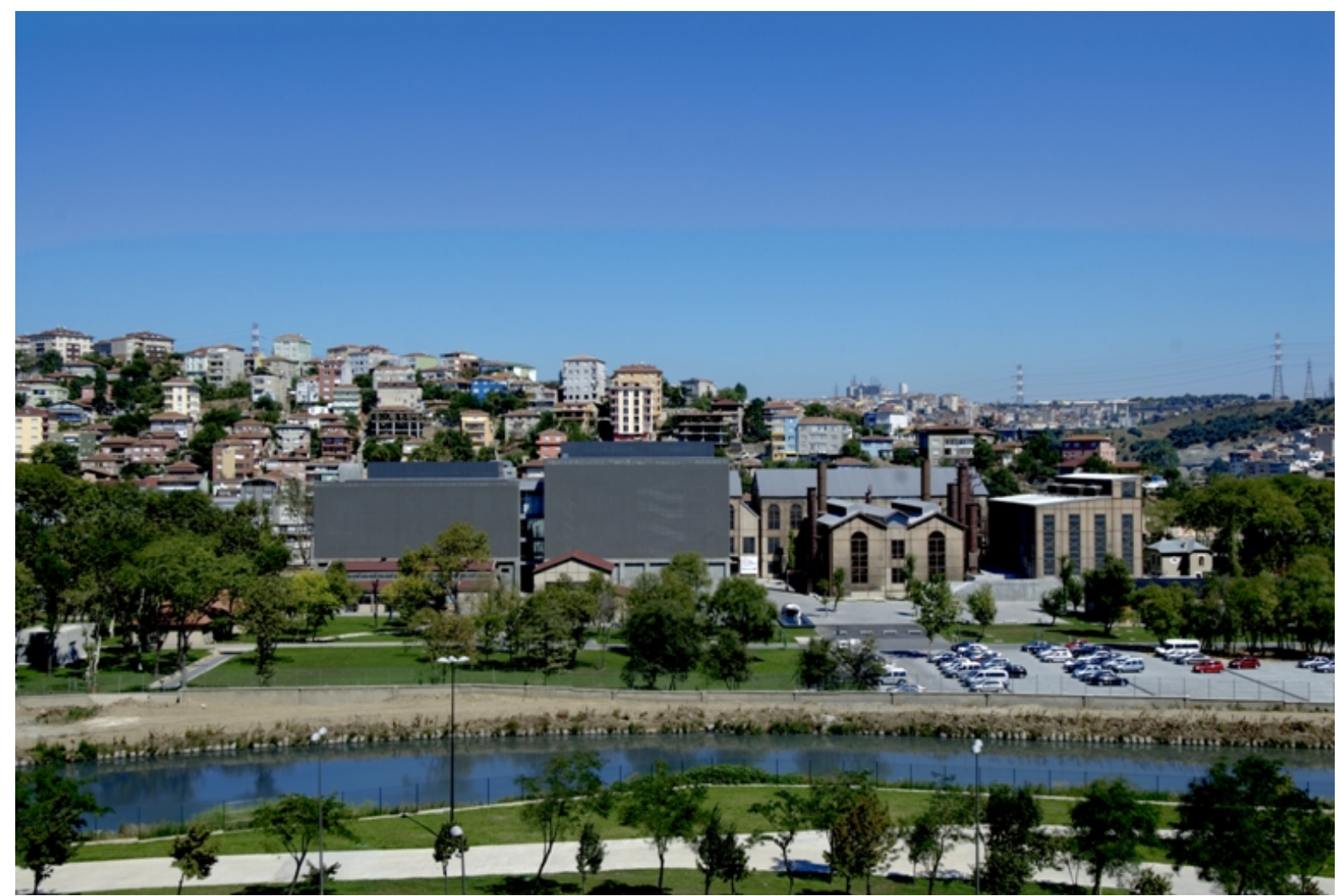

Photo 1. Santralistanbul (URL-1, 2012)

This study will examine two aspects of the Santralistanbul project in discourse around the Haliç Cultural Valley: (1) the effectiveness of the central government and incompetence of the local government, which is similar to other private sector investments, and (2) the importance of the project in Istanbul's cultural platform.

The Silahtarağa power plant was formerly owned by the Ministry of Energy and Natural Resources, and this ownership determined the effectiveness of the key actors in the process. The plant came under protection in 1991, indicating that the regeneration process would be governed from the centre. The discourse of "marketing Istanbul" started during the Dalan period (Bezmez, 2008) and was advanced in the Erdoğan period after the 1994 elections in terms of economic development, globalisation and competition (Öktem, 2006), was shaped with the project of creating the World City in the Ali Müfit Gürtüna period (Yapıc1, 2005) and finally continued with discourse of international capital (Öktem, 2006) and financial and cultural capital in the Kadir Topbaş period. In this context, the Santralistanbul project, which already aimed at creating international dialogue, overlaps with the vision of Istanbul. The opening ceremony of Santralistanbul was delayed for six months so that Recep Tayyip Erdoğan could attend and so that the ceremony could be held one day before the meeting about Turkey's cohesion into the European Union (Şeni, 2009). These factors indicate that the central government supported and attached importance to the project. However, it is difficult to say that local authorities were equally interested. The Fil Bridge Avenue Artists Street project that is located in the Fil Bridge, closed to the Santralistanbul aimed at localisation of art and culture and adoption by the public, was planned to be designed with the cooperation of the Eyüp Municipality and Santralistanbul (Grouiller, 2005), but the project could not be realised and was not included in the strategic plans of the Eyüp Municipality. Besides, the Fil Bridge Avenue is now an auto park area for students of Bilgi and there is no sign of transformation. 
According to the protection-oriented master plan of 2003, the Silahtarağa Power Plant covers an area of 11.83 hectares out of the total 15.44 hectares allocated for cultural facility areas (Eyüp Land Use Plan, 2003). The complete Eyüp Land Use Plan lacks a strategy that can support the Santraistanbul project and direct its possible impact in the district. Today, although the Eyüp Municipality conducts few restoration and cultural infrastructure facilities projects, it is difficult to say if these projects are addressed through upper-scale decisions. This process can be explained by the fact that Santralistanbul is different from the religious and cultural nature of the district (interview, Anıl Sarican Delibay, October $\left.17^{\text {th }}, 2011\right)$ and also by the conservative attitude of the municipality towards continued improvement. In a cultural sense, Santralistanbul is the only museum in the Eyüp district and hosts five out of seven continuously organised international events (compiled through URL-2). According to Roche (1994), international events must be addressed together with tourism objectives and urban planning. However, the major music festivals organised in Santralistanbul, such as Sunday Sky and Efes One Love, failed to break the isolated nature of the area due to a lack of integrated perspective.

The importance of the project on the international platform was accepted by the public, but its role in the Golden Horn Cultural Valley was not sufficiently emphasised. The blue cultural legend in the plans indicates that Santralistanbul is open to the public (Grouiller, 2005; Behar, 2002; Seni, 2009), but only people who enter with special transport vehicles are familiar with the area. This situation could be an exemple of Bourdieu's symbolic violence theory. According to Bourdieu, if the violence was hiding behind the emotional values and carisme of the capital owner who develop manipulation strategies for repruduce his environment, this is the symbolic violence (Bourdieu, 1994; Bourdieu and Wacquant, 1992).

In summary, the central government was effective, while the local governments were uninvolved during the process of private sector investments developed in the Golden Horn Cultural Valley. Santralistanbul can be defined as active on an international scale (Demir and Gamm, 2007; Grouiller, 2005; Candelier and Mantabone, 2009), while the Rahmi Koç Museum was a cultural actor on a local scale (Bezmez, 2008). Although these two flagship projects are important focal points for the city's image, they are disconnected from the discourse of the Golden Horn Cultural Valley.

\section{Local Governments' Large-Scale Investments}

In addition to private sector investments, the Golden Horn Cultural Valley has been the scene of local governments' large-scale investments. The Feshane (interview, Levent Çalıkoğlu, July 16th, 2010), which initially attracted the interest of the Turkish Clothing Manufacturers Association (Munyar, 1990), was planned to be transformed into the Istanbul Museum of Modern Art by the Eczacıbaş1 group. Miniatürk, which represents national culture and was established by IMM (Tureli, 2006) as a huge cultural centre, and the Sütlüce Congress Centre, which was completed after over 10 years of restoration and re-construction by IMM (Gümüş, 2002), are examples of isolated and large-scale local government projects in Golden Horn. The dominant role of the IMM and the nature of the project determine the possible involvement of private sector actors. Therefore, while questioning the role of local government projects in the Golden Horn Cultural Valley, we will also consider the relevant actors and the cultural effectiveness of the projects.

\section{(1) Miniatürk}

Using the build-operate-transfer model (interview, Hasan Işın, May 28th, 2010) and a budget approximately 50 million dollars, Miniatürk was established in 2003 on the Sütlüce coast of the Golden Horn. The project covers an area of 60,000 square metres (URL-3), operated by Kültür A.Ş., a subsidiary of the IMM (Baştürk et al., 2001). The museum is composed of three different sections displaying Anatolia, Istanbul and Ottoman works of art. The museum has alternatively been said to 
resemble a heritage park because of its symbolic references (Türeli, 2006) and a fairy tale because of its disconnectedness with the existing historical fabric (Y1lmaz and Uysal, 2007), a showcase of Turkey with the image of multiculturalism and coexistence where Islamic and Turkish identity are dominant (Yilmaz and Uysal, 2007). By reflecting the multicultural structure of Istanbul and supporting this image in the process of accession to the EU and by reviving Ottoman cosmopolitan nostalgia and reflecting on national identity in the global city, Miniatürk acted in accordance with the discourses of both central and local governments (Tureli, 2006). Miniatürk can be considered an Ottoman and Turkish image in the Golden Horn Cultural Valley with a narrative that does not reflect the cultural and social conflicts during transition periods and has become one of the most important cultural centres of the valley. By attracting an average of 490,000 visitors annually since its opening (Bakbaşa, 2010), it is more crowd-pulling than other cultural institutions. Miniatürk increases the Golden Horn tourism; however, this fact does not mean that these visitors travel to the opposite coast of the Golden Horn (Erden, 2009).

\section{(2) The Feshane}

The Feshane, one example of industrialisation initiatives that gradually increased since the $19^{\text {th }}$ century, was established in Kadırga in 1826 and moved to the Golden Horn in 1833 (Dölen, 1994). Feshane was established to manufacture fezzes for the soldiers of the Ottoman army (Küçükerman, 1988). To create a facility that uses European methods of industrial production (Clark, 1974), it expanded in 1843 with spinning and weaving machinery (Dölen, 1994). The Feshane was almost entirely destroyed by a fire in 1866 (Güler, 1999) but was improved in various ways in subsequent years and then served as a major textile factory during the Republican period.

During the Dalan operations, the Feshane was intended to be demolished on the grounds that it was the most polluting facility on the waters of the Golden Horn (Baştürk et al., 2001). This decision regarding one of the important symbols of industrialisation in the Ottoman and Republican periods brought together many art historians, architects and academics advocating the continued existence of the factory with changing functions, which would be appropriate to the Golden Horn's transforming image and would bring more value to the Feshane, an argument that managed to convince Dalan (Bezmez, 2008).

With this decision, the Feshane first attracted the interest of the Turkish Clothing Manufacturers Association (interview, Levent Çalıkoğlu, July 16th, 2010). The Feshane Culture and Art Fair Centre Regeneration Project (Munyar, 1990) was initiated by the association with a tender in 1988; then, like many other projects initiated in the Dalan period, this project was also suspended during the Sözen period. In addition to conflicts over the execution and operation of the project, the Turkish Clothing Manufacturers Association gave up the project in 1990 (Bezmez, 2008) after a request for an additional building that would be owned by IMM (Munyar, 1990).

Following this period, the Istanbul Biennial was held in 1991, which prompted ideas of establishing the Istanbul Modern Art Museum (interview, Levent Çalıkoğlu, July 16th, 2010) in the Feshane. The Feshane was restored in cooperation with the local government, and, again, despite investments, the project was suspended due to disputes with the management. After the death of Nejat Eczacıbaş1, his daughter-in-law, Oya Eczacıbaşı, took on the project of establishing the Istanbul Modern Art Museum (interview, Levent Çalıkoğlu, July 16th, 2010). Following the 8th Istanbul Biennial in Antrepo, this venue was selected as the location of the Istanbul Modern Art Museum (interview, Levent Çalıkoğlu, July 16th, 2010) meaning that it was founded in Antrepo instead of the Feshane.

The art fair of ArtBosphorus, which began in the Feshane in 2007, moved to the Harbiye Military Museum and Cultural Centre in the following years for reasons of access to and social structure of the district. Although various fair activities currently take place in the Feshane under the operation of 
BELTUR (the enterprise of Istanbul Municipality), this venue attracts neither Istanbulites nor the private sector except during Ramadan festivities and a few local events.

\section{(3) Sütlüce Congress Centre}

Established in 1923 by Ahmad Burhaneddin, Osman Fitr and Markos Logos according to the 1st National Order, the Sütlüce Slaughterhouse was used as the largest slaughterhouse of Istanbul until 1991, after which it became a distribution centre (Salman, 1994). During the Dalan period, several projects were proposed for the slaughterhouse, and it was planned to be regenerated into a cultural centre due to pollution caused by the facility in the Golden Horn's waters (interview, Selçuk Kolay, February $\left.1^{\text {st }}, 2011\right)$. The project was suspended during the period of Sözen but was again initiated in 1994, and with its demolition in 1998, the Sütlüce Congress and Culture Centre regeneration process began (Köksal and Kargın, 2003). With the aim of creating the largest cultural centre in Europe, the construction of the congress centre took 11 years. Because the European Water Forum 2009 was to take place in this congress centre, construction was finally speeded up and it opened for service in early 2009 (Photo 2 ).

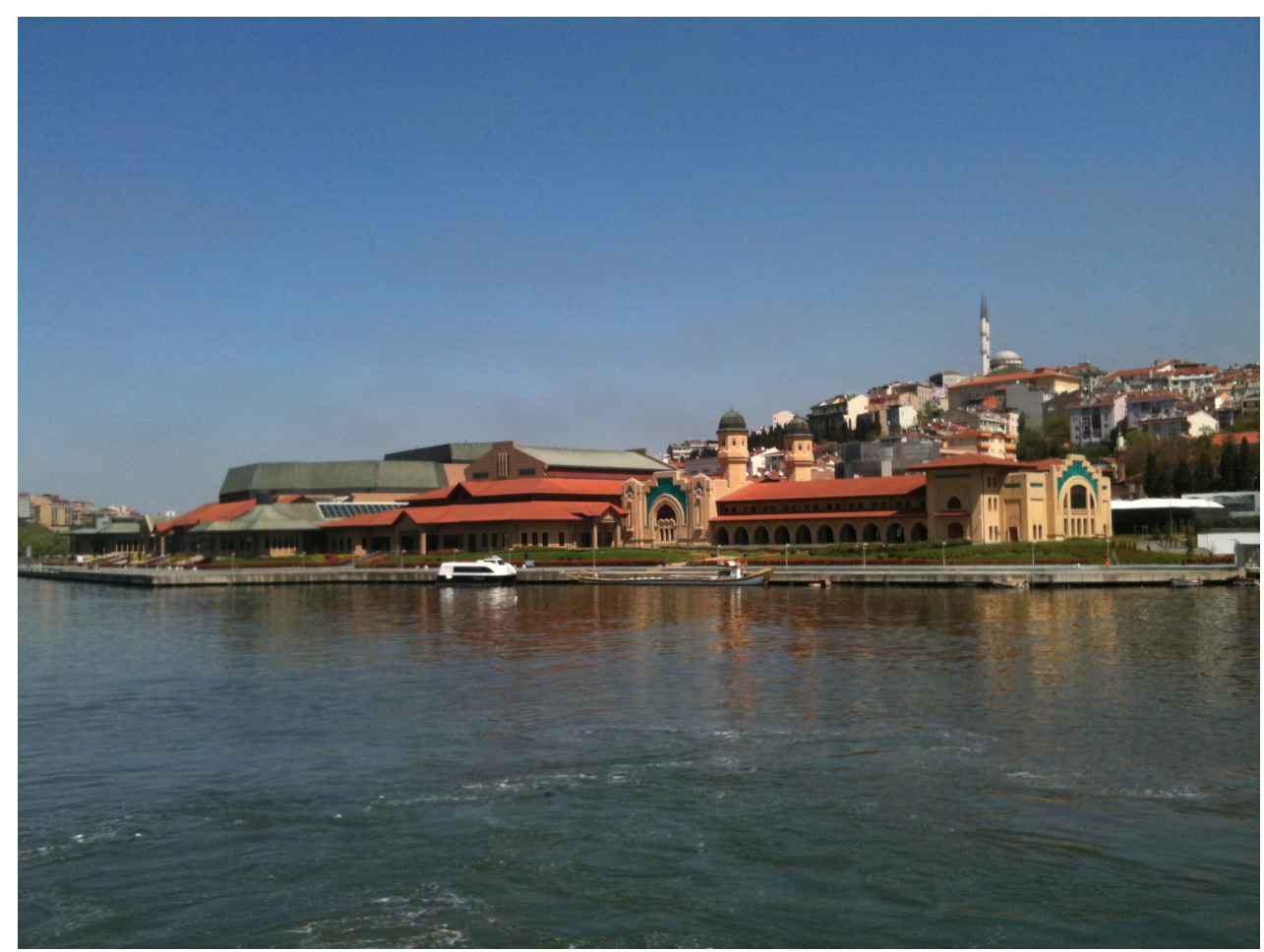

Photo 2. Sütlüce Congress Centre (The archive of Eyüp Municipality, 2011)

As can be observed, the local government projects of the Golden Horn Cultural Valley were shaped over time according to the visions of different political parties because the private sector and civil society organisations were excluded from the process. Because the realisation of the projects took an extended amount of time, these cultural infrastructures remained disconnected from one other, and their visibility increased according to their role and the nature of the events organised. Confirming this idea is the fact that the Feshane, which had attracted the private sector and civil initiatives, was left to its fate; the Sütlüce Congress Centre was once launched as the largest cultural centre of Europe but 
became a ghost in the valley. Miniatürk maintains a higher cultural visibility than the other projects and attracts mostly local visitors, but the fact that it has never been anything more than a tourism destination confirm this opinion.

\section{Urban Regeneration Projects}

Despite regeneration efforts in 1980s in Golden Horn, changes in legislative structure that let the process begin was conceived after 2005, especially with Law on Preservation by Renovation and Utilisation by Revitalising of Deteriorated Immovable Historical and Cultural Properties (Law No. 5366) (also known as Law on Renovation). This law is the main tool for regeneration projects to be implemented at the historical areas. The process began with the classification of Beyoğlu as a renovation zone on February 20th, 2006. Even more, five renovation zones were classified the same year. The municipality of Fatih presented 12 districts for their classification in the renovation zone. The neighborhoods of Fener and Balat were registered as renovation areas on September 13, 2006. However, changes in neighbourhood of Fener and Balat have started before its registration as a renovation area. In the $1990 \mathrm{~s}$, the rehabilitation of this historial neighbourhood has begun with the participation of international actors such as UNESCO, the European Union, IFEA, national and local actors. This Fener and Balat Neighborhood Rehabilitation Project is an example of progressive strategies that attempt to implement the socio-economic development of neighborhoods by conserving its historical heritage, which is completely different of the renovation vision in 2006. Subsequently, this project was abandoned and set up with the renovation project developed by the municipality of Fatih and public actors at the national level. This new project plays down conservation of the neighbourhood and its socio-economical structure of inhabitants, and prioritises touristic/commercial "image" of the neighbourhood. These two projects carried out in the same neighborhoods show us how the conservation and regeneration vision could change in Golden Horn and allow us to understand the difference in terms of stakeholder participation in the decision-making process. In this regard, the regeneration process of the case of Fener Balat neigborhood is different from the other renewal areas of Golden Horn.

\section{Fener-Balat as a Rehabilitation Project}

The first study to be conducted in the region was the Fener-Balat rehabilitation project, which began in partnership with UNESCO, the Fatih Municipality and the European Commission in 1997. The rehabilitation area was 16.2 hectares, including 1.401 parcels, 71 city blocks and 1.219 buildings, and the number of residents approximately totalled 18.000 (Stoquart and Yerasimos, 1998). The neighbourhood of Fener, where the Greek Orthodox Patriarchate is located, and the neighbourhood of Balat, which was known as the Jewish quarter, have undergone social change, with increases in the industrial activities of the Golden Horn in the 1960s; today, they primarily host immigrants from the Black Sea region (Stoquart and Yerasimos, 1998). As observed from the feasibility report completed by IFEA (Institut Français d'Etudes Anatoliennes), the European Commission and the Fatih Municipality in 1998, the inhabitants of the region are living below the poverty line (FSWW, 2004; Stoquart and Yerasimos, 1998). For instance, the study conducted within the scope of the feasibility study determined the amount that was required to meet the rent and food costs of four people as $\$ 500$. In total, $70 \%$ of the inhabitants of the Fener and Balat districts live on less than $\$ 300$ (Stoquart and Yerasimos,1998).

The main objective of the project is to improve the quality of life in the region and to show that a historical centre such as Istanbul is not trapped between the alternatives of simple renovation work and tourism-oriented restoration (Stoquart and Yerasimos, 1998). The project concentrated on four targets: improving the housing stock, which was completely destroyed and required intensive intervention in the region; increasing the rate of job creation and education; creating a revitalisation process by

Submit Date: 10.04.2019, Acceptance Date: 10.07.2019, DOI NO: 10.7456/10904100/003

503

Research Article - This article was checked by Turnitin

Copyright $(\mathbb{C}$ The Turkish Online Journal of Design, Art and Communication 
protecting the inhabitants of the region; and improving the physical and social infrastructure of the region (Stoquart and Yerasimos, 1998). The content of the program includes the titles of restoration, social centre, the Balat Market and waste management (URL-4) (Photo 3). One important aspect of the project is coordinating the process with the public's participation. To minimise the possible effects of gentrification, the owners of the restored houses have been forbidden from selling their homes or increasing rents for five years (Ercan, 2010). The project was selected as a sample project by UNESCO and ICOMOS due to the strong participant pool (Ercan, 2010).

For Sadettin Tantan, the mayor of Fatih District at the time, the rehabilitation project was important in the sense of manifesting the potential importance of the Fener and Balat neighborhoods (interview, Ersin Alkan, December 20th, 2011). However, the project slowed due to a number of problems, including the following: the requirement of longer than predicted technical studies on the existing building materials for transforming the buildings into multi-family housing due to immigration; the inhabitants protesting the project and its staff because they believed its true goal was to create a second Vatican in the region (interview, Ersin Alkan, December 20th 2011); and the inability to make five-year projections (Bezmez, 2008). The public's discontent with these problems was also reflected in the elections, and Mustafa Demir took the place of Sadettin Tantan (Bezmez, 2008). Following the contract between the homeowners and the Fatih District Municipality, the Pekerler Construction Company won the tender and began restoration work in 2005 .

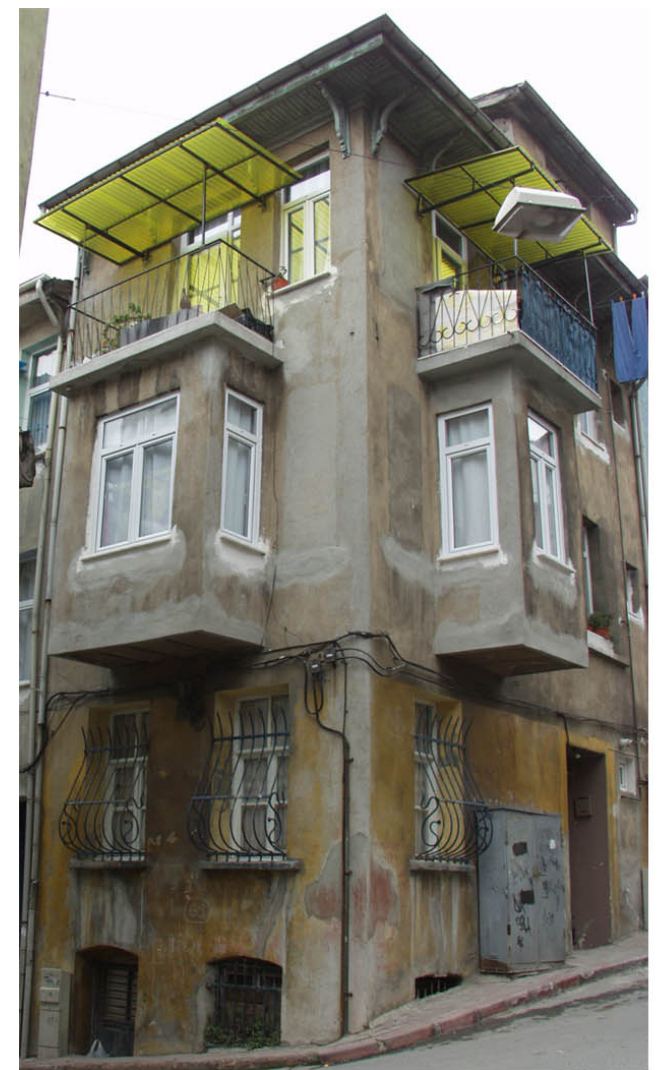

Before the restoration

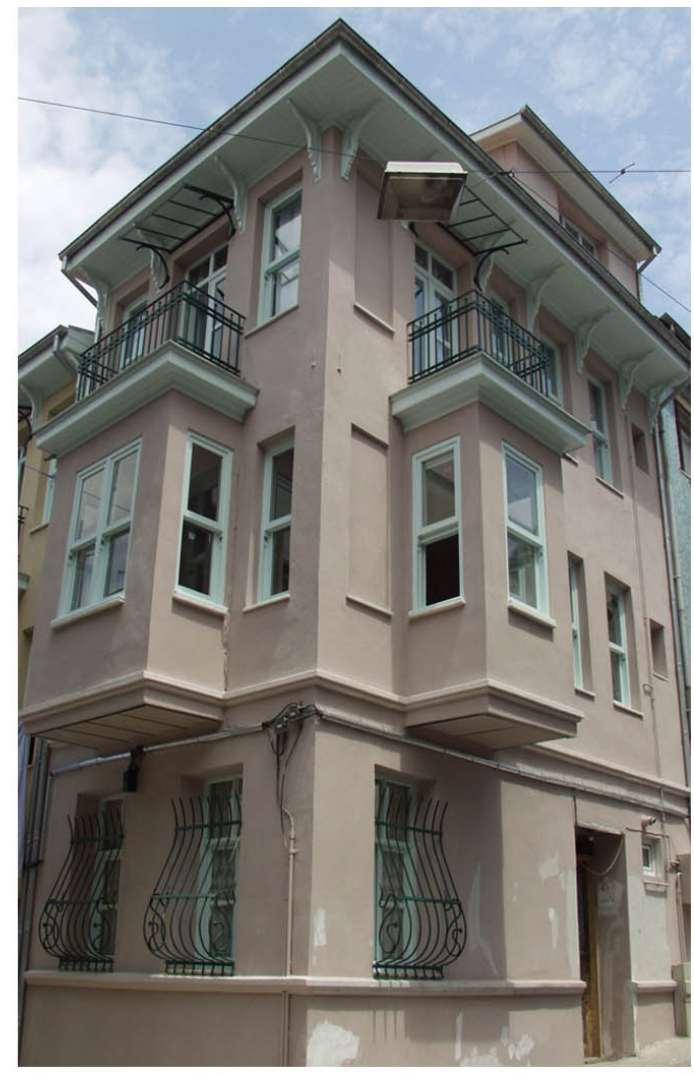

After the restoration

Photo 3. Fener Balat Rehabilitation Project (URL-4, 2011) 


\section{Fener-Balat as a Renewal Area}

Another important development that brings urban regeneration of the region to the agenda is related to legislation. As soon as the Law on Renovation (No. 5366) was enacted in 2005, the declaration of historical sites as renewal areas and the implementation of the processes began to be discussed.

The objective of this law was to ensure that conservation areas registered and declared conservation sites by the councils for conservation of cultural and natural property and that conservation zones that are run-down and on the verge of losing their specificity are reconstructed and restored and, hence, to develop housing, trade, culture, tourism and social facilities in these areas, to take precautions against natural disaster risks and to protect by renovation and by revitalisation use real historical and cultural property. The law gives the authority to determine renovation areas to the special provincial administrations and municipalities, and these authorised administrations become the sole judge of the region. In addition to the authorised administrations, the law also authorises the Housing Development Administration and other public institutions or individuals and legal entities to implement renovation projects.

Regarding the law, the conflict of planning discipline, the relationship between conservation and renovation, the proposed structure of participants, the actors involved in the process and, in particular, the implementation of renovation projects were added to the urban planning agenda. The law was mainly based on renovating run-down sites against the risk of earthquake. Today, the law raises concerns regarding the destruction of historical heritage sites. As identified in the implementation of the law's regulations (Date of enactment: 11/17/2005; Issue No. of the Official Gazette: 26023; Date of the Official Gazette:12/14/2005), addressing the renovation areas as preliminary projects that were evaluated independent from other plans developed for the region contradicts the discipline of planning and results in a non-integrated approach; hence, the preliminary project defined in the IMM Building bylaws refers to the plan and legislation that is in effect (Dinçer, 2009).

Another dilemma posed by the law involved addressing renovation projects as physical implementation projects, thereby ignoring the development of the region's socio-economic structures. This case provided the basis for configuring renovation projects in a centralised manner, which excluded locals from the decision-making process. Finally, the victimisation of property owners during the expropriation process is another point that must be addressed by the law. For a case in which a property owner does not approve of renovating a building that will serve tourism and housing functions, the law gives the authority of expropriation to public institutions and the authority of transfer of public properties to third parties (Dinçer, 2009).

The speed of regeneration projects that take place in historic neighbourhoods, such as Fatih and Beyoglu, and the role attributed to the projects also attracted the attention of the international press. For example, the daily Guardian covered the regeneration process in Istanbul with the headline "Istanbul sees history razed in the name of regeneration" (see URL-5). With Law No. 5366, the paradox of protection and renovation emerged; the implementations that stand apart from international norms violate the relationship of human-cultural heritage and draw reactions from residents in areas of renovation (Ahunbay, 2011: 82).

Renewal areas have become one of the primary concerns of the Fatih District Municipality, and the Fener-Balat neighborhoods were declared renewal areas on April 22, 2006 (Fatih District Municipality Annual Report, 2009). Renovation projects were approved before the termination of rehabilitation projects. "The earthquake risk and the possibility of collapsing" were emphasised as the main reasons for this situation (interview, Mustafa Çiftçi, November 15th, 2011; interview, Ferda Karakaya, November 15th, 2011; interview, Davut Akdeniz, November 15th 2011). The project, which includes 195 civil architecture samples and 34 monuments in an area of 279,345 square metres (Fatih District Municipality Annual Report, 2009), was transferred to GAP construction Company in 2007 (interview, İbrahim Güntekin, December 20th, 2011). In total, 69\% of this area is planned as 
residential space, $12 \%$ as commercial space, $8 \%$ as office space and $2 \%$ as culture space (URL-6). Additionally, $58 \%$ of the property ownership was distributed to the private sector and $42 \%$ to property owners; the Fatih District Municipality did not play an active role in the process (Dinçer, 2010). Real estate prices that increased during the rehabilitation project showed a significant augmentation after the announcement of the renovation project. For example, while the price of a square metre on Fethiye Avenue was 625 TL in 2008, it rose to 1920 TL in 2010 (Fatih District Municipality, 1990 - 2010).

Urban regeneration projects of the Golden Horn Cultural Valley are one of the main instruments used for regenerating the region into a tourism and cultural centre. While the Fener-Balat rehabilitation project is considered a building-scale restoration project by the local authorities (interview, Ferda Karakaya, November 15th 2011), in contrast to the renewal project, this project won the public's approval (interview, İbrahim Güntekin, December 20th 2011; interview, Ersin Alkan, December 20th 2011; interview, Recep Savaş, December 21st 2011; interview, İrfan Pulcu, December 21st 2011). The neighbourhood of Fener Balat, which did not attract the attention of the private sector and potential gentrifiers, was once again brought to the agenda with the renovation project. It would not be wrong to say that these projects conducted in the Golden Horn Cultural Valley were used by local governments to accelerate a regeneration process that was progressing slowly.

\section{CONCLUSION}

The Golden Horn achieved its industrial identity in the late Ottoman period and preserved this identity during the Republican period while changing socially and economically with the planned industrial areas. The 1980s stand as an important turning point when the industrial identity of the region began to disappear with the Dalan operations. This process slowed down during the Sözen period and revived with the discourse of a "cultural valley" during the period of Ali Müfit Gürtuna, which has continued to the present day. This discourse dating back to the 1980s has been seen in various projects since. In this article, we categorised these projects in terms of the involvement of the actors, the type of the promoter and the content of the project. Even if their content as well as their target is different, the problems in the organisazion between actors possess many similitudes and influence the implementation of these projects in Golden horn. This similitude between projects allows us to see why the regeneration process in Golden Horn stayed still for many years, which can be categorised under three headings.

\section{Processes vary according to the actors:}

The projects are shaped according to the positions and power of the actors involved. The effective presence of the Ministry of Culture and Tourism in private sector projects accelerates the process and, in a way, excludes the local actors. In the public shaped IMM projects, the actors involved changed due to different governments' policies, and the planned projects were evaluated with different priorities. This situation has slowed projects' physical and contextual processes. The urban regeneration projects gained momentum in 2005 with the urban renewal law and emerged as private sector-led projects that aim to increase the tourism potential of the region. Therefore, the position of the projects in the Golden Horn Valley was shaped according to the overall purpose and goal of the project, degree of involvement and power of public actors. For instance, Feshane was one of the potential flagship project for many local governor. However, the interruption of a continuous vision and different cultural context that actors want to build in Feshane decreases the importance of the place and create an infrastructure that host various cultural events rather than a flagship project that strengthen cultural image of Golden Horn. Similar situation showed up in Fener Balat neighbourhood. First of all, international and local actors have established rehabilitation project with a protection of historical build environment vision. Later on, with the change of public actors, this protectionist vision has been ignored and a brand new vision that put forward new tourism and commercial infrastructure has adopted.

Submit Date: 10.04.2019, Acceptance Date: 10.07.2019, DOI NO: 10.7456/10904100/003 


\section{Lack of integrated vision:}

Various projects have been produced to transform the Golden Horn into a cultural valley since the 1980s. However, it is difficult to accept the presence of an upper-scale plan and a complete vision of the plan that covers the entire Golden Horn region and directs sub-scale projects. Due to the lack of a master plan explicitly defining the cultural axis of the region (save the Istanbul Environmental Master Plan), the cultural valley discourse was developed through isolated projects and failed to create a regional cultural brand.

\section{Disconnected cultural visibility:}

The visibility of the projects in Istanbul's cultural platform depends on the actors and the contents of the projects. Private sector projects with an international cultural vision organised major events and strengthened the brand value of Istanbul's cultural infrastructure but remained as symbolic powers behind closed doors. The cultural visibility of public investments was determined by the content of the project and the vision of the existing local government regarding the project. As observed in the Feshane and Sütlüce Congress Centre projects, due to various actors being involved at different phases of the projects, the process was prolonged, which affected their status in the cultural platform. Local governments were in substantial agreement with the vision of Miniatürk, which became the cultural focal point for local visitors. Therefore, it can be argued that in general, the projects possessed significant cultural identities, but the valley was far from creating a cultural brand.

The regeneration process of the Golden Horn Cultural Valley shares the same implementation solutions as other examples of international cultural-oriented regenerations. However, the Golden Horn differs from other international examples in terms of the rapid increase in land prices, the process of gentrification and the private sector's interest in the region. The ownership of the actors in the process of implementing the projects, the local governments' attitudes towards the concept of a cultural valley, the roles ascribed to the projects and the overall goals and objectives of the projects are among the factors that differentiate this process. The slow development of the Golden Horn during this regeneration process has experienced a significant change with the Law on Renewal in 2005. Rising property prices on both sides of the valley, private sector initiatives and frequent cultural events also confirm this situation. Local governments in the Golden Horn region cannot be considered the most active parties during the process of regeneration when the concepts of culture and regeneration became significant to the identity of Istanbul. Renovation projects that aim to accelerate the regeneration of the Golden Horn threaten the historical heritage of the region. Problems in the rapid development process are similar to problems encountered during the 30-year regeneration process. Rapid-regeneration problems include lack of an integrated approach to planning, lack of communication between actors and disconnection between projects, which then creates isolated culture centres. Therefore, while the Golden Horn was in an advantageous position during the slow regeneration period, it has begun to lose that advantage today.

\section{REFERENCES}

Ahunbay, Z. (2011). Kentsel Korumada Temel İlkeler ve Fener-Balat, mimar.ist, vol:42, Istanbul, p:85

Aksoy, A., Açıbaş F. and Akman A. (2007). "Silahtarağa Elektrik Santralinin Hikayesi" Silahtarăga Elektrik Santrali 1910-2004 Asu Aksoy (ed), İstanbul Bilgi Üniversitesi Yayınları, İstanbul. 
Arolat, E., Bilgin İ., Sayın N. and Tümertekin Han (2007). "Santralistanbul”, Yapı Dergisi, vol:313, Istanbul, p:52-70.

Aydemir, I. (2008). "İki Fransız Mimar Henri Prost ve August Perret'nin İstanbul ile ilgili Çalışmaları", Megaron YTU Arch. Fac E-Journal, vol:3, Issue 1, Istanbul, p:104-111.

Bakbasa, C. (2010). Istanbul'da Müzeler Sektörel Araştırma Raporu: Temel Yapısal Özellikler, Fırsatlar ve Tehtidler, Politika Önerileri, Türkiye Kültür ve Turizm Bakanlığ 1 , accessible at www.istanbulkulturenvanteri.gov.tr [access date: 12 June 2011]

Behar, D. (2002). Les universités privées d'Istanbul, Les Dossier de l'IFEA, no: 10, Institut Français des Etudes Anatoliennes, Istanbul, accessible at www.ifea-istanbul.net/dossiers ifea/Bulten_10.pdf, [accessed date on 06 July 2010]

Baştürk, A., Mete B. and Altun L. (2001). "İstanbul Büyükşehir Belediyesi Haliç Dönüşüm Projeleri”, Haliç 2001 Sempozyumu Kitabı, Istanbul, p:36-63.

Bezmez, D.(2008). "The Politics of Urban Waterfront Regeneration: The Case of Haliç (the Golden Horn), Istanbul", International Journal of Urban and Regional Research, vol:32, issue:4, p:815-840.

Beyoğlu Municipality (1990-2010), Real Estate Values, https://webserver.beyoglu.bel.tr/web/guest/5, [accessed date on 23 September 2012]

Bilsel, C. (2011). "Les Transformations d'Istanbul: Henri Prost's planning of Istanbul (1936-1951)", ITU $A \mid Z$, vol: 8, no:1, Istanbul, p:100-116.

Bilsel, C. (2007). "Remodelling the Imperial Capital in the Early Republican Era: the Representation of History in Henri Prost's Planning of Istanbul", Power and culture: identity, ideology, representation Osmond J. and Cimdina A. (ed), Pisa : Plus-Pisa University Press, Pisa, p: 95-115.

Bourdieu, P. and Wacquant L.J. (1992). Réponses, pour une Antropologie Réflexive, Seuil Publication, Paris

Bourdieu, P. (1994), Raisons Pratiques sur la théorie de l'Action, Seuil Publication, Paris.

Candelier, C.M. and Montabone, B. (2009). "Istanbul, une internationalisation forcée ?", EchoGéo (online), vif 2009, accecible at http://echogeo.revues.org/11523, [accessed on 09 December 2010]

Cengizkan, A. and Köksal, G. T. (2004). "Silahtarağa-Bir Endüstri Arkeolojisi Anıtı", Arradamento Mimarlık Dergisi, July-August, p: 69-82.

Cengizkan, A. (2006). "Istanbul Silahtarağa Elektrik Santrali Türkiye'de Fabrika ve İşçi Konutları", dosya 3, The Chamber of Architects in Ankara, no:45, Ankara, p:14-18, accessible at http://www.mimarlarodasiankara.org/dosya/dosya3.pdf, [accessed on 01 August 2008].

Clark, C. E. (1974). "The Ottoman Industrial Revolution", International Journal of Middle East Studies, Vol: 5, No. 1, pp. 65-76.

DCMS (2004). "Culture at the Heart of Regeneration", London: Department for Culture, Media and Sport, http://www.culture.gov.uk/images/consultations/DCMSCulture.pdf, [accessed in August 2005]. 
Demir, G. and Gamm, N. (2007). Silahtarağa Santral becomes Santralistanbul Museum, Hürriyet Daily News, accessible at http://www.hurriyetdailynews.com/default.aspx?pageid=438\&n=silahtaraga-santral-becomessantralistanbul-museum-2007-09-08 [accessed on August 2009].

Dinçer, I. (2009). "Kentsel Koruma ve Yenileme Sorunlarını Örnekler Üzerinden Tartışmak: Süleymaniye ve Tarlabaşı", Planlama.org (online), accessible at http://www.planlama.org/new/doc.dr.-iclal-dincer/kentsel-koruma-ve-yenileme-sorunlarini-ornekler-uzerinden-tartismak-suleymaniyeve-tarlabasi.html, [accessed on 17 September 2010]

Dinçer, I. (2010). "The Dilemma Of Cultural Heritage - Urban Renewal: Istanbul, Süleymaniye and Fener-Balat", paper presented in 14th IPHS Conference, 12-15 July 2010 Istanbul.

Dölen, E. (1994), "Feshane”, Dünden Bugüne İstanbul Ansiklopedisi, vol:3, Türkiye Ekonomik ve Toplumsal Tarih Vakfi, İstanbul, p: 297-298.

Ekinci, O. (1994), İstanbul'u Sarsan On Yıl, Anahtar Kitaplar Yayınları, Istanbul.

Ercan, A. M. (2010). "How to Achieve Sustainable Conservation in The Historic Housing Neighbourhoods Of Istanbul?" Paper presented in 14th IPHS Conference, 12-15 July 2010 Istanbul.

Erden, D. (2003). Kentsel Yenileşmede Bir Araç Olarak Dönüşüm Projeleri, Mimar Sinan University, Urban and Regional Planning Department, unpublished PhD thesis, Istanbul.

Erden, D. (2009). Haliç'te Dönüşüm ve Tarihsel Süreklilik, conference paper at Osmanlı Bankası Arşiv ve Araştırma Merkezi, Istanbul

Eroğlu V., Sarıkaya H., Öztürk İ., Yüksel E. and Eryılmaz G. (2004). "Haliç'in Dünü, Bugünü ve Yeniden Doğuşu”, Dünü ve Bugünü ile Haliç Sempozyum Bildirileri Göncüoğlu S. F. (ed), Kadir Has University, Istanbul, p:12-20.

Ethem, Ç. (2009). 69 y1llık emek göründü, Birgün Gazetesi - 24 April 2009 accessible at http://www.birgun.net/life index.php?news code $=1240562187 \&$ year $=2009 \&$ month $=04 \&$ day $=24$ [acc essed on 17 September 2010]

Evans G. (2005a). "From cultural quarters to creative clusters - creative spaces in the new city economy", The sustainability and development of cultural quarters: international perspectives, Legner, M (ed.), Stockholm: Institute of Urban History, p:32-59.

Evans, G. (2005b). "Measure for Measure: Evaluating the Evidence of Culture's Contribution to Regeneration", Urban Studies, 01, p:959-983, http://www.scholars-onbilbao.info/fichas/16EvansUS2005.pdf, [accessed in February 2006].

Evans, G. and Shaw, P. (2004). "The Contribution of Culture to Regeneration in the UK: A Review of Evidence, a Report to the Department for Culture Media and Sport" London: LondonMet., http://www.culture.gov.uk/images/consultations/ADCMSFinall.pdf, [accessed in February 2006].

Eyice, S. (2002). “İstanbul'un İmar Planı Raporları”, İstanbul Dergisi, no:43, Tarih Vakfı Yayınları, Istanbul, p:20-24.

Eyüp Land Use Plan 1/5000 (2003). Municipality of Eyüp. 
Fatih District Municipality Annual Report (2009). accessible at http://www.fatih.bel.tr/bpi.asp?caid=403\&cid=543, [accessed on 2 March 2011]

Fatih District Municipality (1990-2010). Real Estate Values, complied through https://ebelediye.fatih.bel.tr/alfa/servlet/hariciprogramlar.online.rayic?caid $=1449$ [accessed on 2 March 2011]

Foundation for the Support of Women's Work (FSWW) (2004). Fener-Balat Districts Survey Report, Istanbul.

Garcia, B. (2004). "Cultural Policy and urban regeneration in western european cities", Local Economy, Vol.19, No.4, p:312-326.

Garcia, B. (2005). "Deconstructing the City of Culture : The Long-term Cultural Legacies of Glasgow 1990”, Urban Studies, Vol. 42, Nos 5/6, p:841-868.

Grouiller, J. (2005). La reconversion de la centrale électrique Silahtaraga. Analyse d'une opération de reconversion de friche industrielle urbaine au travers de ses références et des acteurs impliqués, unpublished Urban Planing Master thesis, Université Paris 8, Paris.

Gümüş, K. (2002). Dev kültür merkezi 'hayaleti', Radikal Gazetesi-26.06.2002 (http://213.243.16.14/haber.php?haberno=41596) [accessed on 6 March 2009]

Gümüş, K. (2011). Haliç Nezihleştirmeye Direniyor, in "Haliç’teki Dönüşüm Süreci Üzerine Görüşler”, mimar,ist, vol:42, Istanbul, p:63-65.

Günay, Z. and Dökmeci, V. (2011). "Culture-led regeneration of Istanbul waterfront: Golden Horn Cultural Valley Project”, J.Cities, vol: 29, issue 4, p:213-222.

Güler, A.S. (1999). "Sanayi Devrimi, Osmanlı Sanayi Mimarisi ve Feshane Üzerine Bir Ön Değerlendirme," in Essays in Honour of Aptullah Kuran Çiğdem Kafesçioğlu, Lucienne ThysŞenocak, and Günhan Danışman (ed), Yapı Kredi Publication, p:387-399.

Hetherington, K. (2008). "The Time of the Entrepreneurial City: Museum, Heritage and Kairos", in Consuming The Entrepreneurial City Image, Memory, Spectacle, Cronin, A. M. and Hetherington, K. (eds.), New York: Taylor \& Francis, p:273-294.

İbişoğlu, S. V. (1991). Lengerhane Restorasyon Projesi, Istanbul Technical University, Department of Architecture, unpublished master thesis, Istanbul.

Kayserilioğlu, R.S. (1999). Dersaadet'ten İstanbul'a Tramway, vol:2, İETT Yayınları, İstanbul. Kara, H.F.E. (1994). "Silahtarağa", Dünden Bugüne İstanbul Ansiklopedisi, vol:7, Türkiye Ekonomi ve Toplumsal Tarih Vakfi, İstanbul, p: 554-556.

Karaman, F. (2012). Fotoğraflı Bir "Sürgün”, Birgün Gazetesi, 18 Şubat 2012, accessible at http://bianet.org/biamag/diger/136257-fotografli-bir-surgun, [accessed on 3 March 2012].

KEA (2006). "The Economy Of Culture in Europe", EC Study, European Commission, DirectorateGeneral for Education and Culture, Brussels.

Keleş, R. (2003). "Urban Regeneration in İstanbul”, paper for Priority Action Programme, Regional Activity Center, Split. 
Keyder, Ç. and Öncü, A. (1993). "İstanbul Yol Ayırımında", İstanbul Dergisi, no: 7, Tarih Vakfı Yayınları, Istanbul, p: 28-35.

Keyder, Ç. (2000). “Arka Plan”, İstanbul Küresel ile Yerel Arasında Keyder Ç. (ed), Metis Yayınları, p:9-40.

Kılıç, A. and Yenen, Z. (2001). "Haliç için Bir Planlama Modeli Önerisi”, Haliç 2001 Sempozyumu Kitabl, Istanbul, p:64-77.

Köksal, G. T. (1996). Haliç Tersaneleri'nin Tarihsel-Teknolojik Gelişim Süreci ve Koruma Önerileri, Istanbul Technical University, Department of Architecture, unpublished master thesis, Istanbul.

Köksal, G. T. (2004), "Haliç Tersaneleri'nin Tarihsel-Teknolojik Gelişimi Süreci ve Geleceği”, Dünü ve Bugünü ile Haliç Sempozyumu, 21-23 May 2003 Istanbul, Kadir Has Universitesi Yayınları, pp: $411-420$.

Köksal, G. T. and Kargın, H. H. (2003). "Haliç’teki endüstri mirasının geçmişi ve geleceği”, Dünü ve Bugünü ile Haliç Sempozyum Bildirileri, Kadir Has Üniversitesi, p: 431-443.

Köksal, G. T. and Ahunbay, Z. (2006). "Istanbul'daki endüstri mirası için koruma ve yeniden kullanım önerileri”, itüdergisi/a mimarlı, planlama, tasarım, vol:5, no:2, part:2, Istanbul, p:125-136.

Kunzmann, K.R. (2004). "Culture, creativity and spatial planning”, TPR, 75(3), 337-358.

Küçükerman, Ö. (1988). Türkiye Giyim Sanayii Tarihindeki Ünlü Fabrika, Sümerbank Yayınları, Ankara

Landry, C. (2006). The Art of City Making, Earthscan, London and Sterling.

Munyar, V. (1990). Feshane Projesi Kald1, Milliyet Gazetesi, 22 June 1990, Istanbul, p:5

Müller-Wiener, W. (1992). "15-19 yüzyılları arasında İstanbul'da İmalathane ve Fabrikalar" Osmanlılar ve Batı Teknolojisi Yeni Araştırmalar Yeni Görüşler içinde (ed.) Ekmeleddin İhsanoğlu, Edebiyat Fakültesi Basımevi İstanbul, p:53-120.

Öktem, B. (2006). "Neoliberal Küreselleșmenin Kentlerde İnșası: AKP’nin Küresel Kent Söylemi ve İstanbul'un Kentsel Dönüșüm Projeleri”, Planlama Dergisi, Journal of the Chamber of City Planners no:36, Ankara, p:43-63.

Öktem, B. (2011). “Istanbul'da Neoliberal Kentleşme Modelinin Sosyo-Mekansal Izdüşümleri”, İ.Ü. Siyasal Bilgiler Fakültesi Dergisi, no:44, p:23-40

Paşaoğlu, A. (2007). "Bilgi”nin Çekim Merkezi, an interview with Ihsan Bilgin, Yenimimar, no:53, eylül 2007

Roche, M. (1994). "Mega events and urban policy”, Annals of Tourism Research, vol:21, issue:1 pp. $1-19$.

Salman Y, (1994). "Sütlüce Mezbahası", Dünden Bugüne İstanbul ansiklopedisi, vol: 7, Tarih Ekonomik ve Toplumsal Tarih Vakfi,p: 119-121. 
Stoquart, R. and Yérasimos, S. (1998), Projet de réhabilitation des quartiers de Balat et de Fener, Fatih Municipality, European Union and UNESCO.

Suhen, H. (1994). "Planlama”, Dünden Bugüne İstanbul Ansiklopedisi, vol:6, Türkiye Ekonomik ve Toplumsal Tarih Vakfi, Istanbul, p: 265-275.

Şeni, N. (2009). "Le mécène, un acteur méconnu de la ville", Transcontinentales, No:7, accessible at www.transcontinentales.revues.org/374, [accessed on 09 July 2011]

Şentürk, O. (2010). Gayrimenkulde yeni trend Sütlüce, Hürriyet Gazetesi, 16 April 2010 accessible at http://www.hurriyet.com.tr/ekonomi/14431261.asp [accessed on 15 March 2011]

Tekeli, İ. (2001). "Dünya Kenti Olma Süreci İçinde Akımlar Mekanını Yeniden Biçimlendiren İstanbul”, Istanbul Dergisi, no:37, Tarih Vakf1 Yayınları, p:88-93.

Teske, D. (2006). "Sites And Sights: The Urban Museum in a Changing Urban Structure", European Studies, 23, p: 259-274.

Türeli, İ. (2006). “Modeling Citizenship in Turkey’s Miniature Park”, TDSR, vol: 17, no:2, p:66-70

UNCTAD (2008). "Creative Economy Report 2008, The Challenge of Assessing the Creative Economy : towards Informed Policy-making”, United Nations.

UNCTAD (2010). “Creative Economy : A Feasible Development Option”, United Nations.

Yapıc1, M. (2005). “Gündemdeki Planlar/Projeler Kent: İstanbul”, Mimarlık Dergisi, no: 322, Istanbul, $\mathrm{p}: 22-25$.

Y1lmaz, S.., Uysal, SS. (2007). "MiniaTurk: Culture, History and Memory in Turkey in Post-1980s", NaMu, Making National Museums Program, Setting the Frames, Aronsson, P. and Hillström, M. (eds), 26-28 February, Norrköping, p:115-125.

Yücetürk, E. (2001). Haliç Silüetinin Oluşum - Değişim Süreci, Haliç Belediyeler Birliği, Istanbul. URL-1, (2012) http://www.santralistanbul.org/ [accessed on 10 October 2012]

URL-2, (2011) http://envanter.gov.tr/ [accessed on 21 August 2011]

URL-3, (2011) miniaturk.com.tr [accessed on 31 October 2011]

URL-4. (2011) www.fenerbalat.org [accessed on 31 August 2011]

URL-5, (2011) http://www.guardian.co.uk/world/2012/mar/01/istanbul-city-urban-renewal [accessed on 11 December 2011]

URL-6, (2011) www.calik.com [accessed on 21 August 2011]

\section{Interviews}

An11 Sarıcan Delibay, urban planner in Eyüp Municipality, on October 17th , 2011

Davut Akdeniz, director of the Süleymaniye renewal project in Fatih Municipality, on November 15th, 2011

Ersin Alkan, journalist, on December 20th, 2011

Ferda Karakaya, director of the Fener Balat renewal project in Fatih Municipality, on November 15th, 2011

Ferhan Yeltırak, citizen living in Hasköy, on February 4th, 2011

Hasan Işın, event coordinator of Kültür A.Ş, on May 28th, 2010

Submit Date: 10.04.2019, Acceptance Date: 10.07.2019, DOI NO: 10.7456/10904100/003 
İbrahim Güntekin, director of Febayder association, on December 20th, 2011

İbrahim Sayfi, owner of the restaurant Lale Lokantasi on February 4 th, 2011

İrfan Pulcu, designer based in Fener district, on December 21 st, 2011

Levent Çalıkoğlu, curator of Istanbul Modern, on July 16th, 2010

Murat Karakaya, hairdresser working and living in Hasköy on February 4th, 2011

Mustafa Çiftçi, deputy manager of Fatih Municipality, on November 15th, 2011

Recep Savaş, inhabitant in Balat district, on December 21st, 2011

Selçuk Kolay, ex-manager of Rahmi Koç Museum, on February 1st, 2011

Selen İşyar, manager of marketing and public relation of Rahmi Koç Museum, on February 3rd ,2011

Serhan Ada, coordinator of the cultural management programme in Bilgi University, on November 16th, 2011

Sinan Atabey, owner of a real estate agency, on February 4th, 2011

Süleyman Kul, owner of drycleaning shop on February 4th, 2011

Şuayip Korkmaz, ex-director of Planning Department of Beyoğlu Municipality, on September 14th, 2011

Yeşim Anadol Zengin, collection manager of Rahmi Koç Museum, on February 3rd, 2011 